\title{
Ecological studies on the decomposition rate of fish carcasses by benthic organisms in the littoral zone of Lake Constance, Germany
}

\author{
Katrin Premke ${ }^{1 *}$, Philipp Fischer ${ }^{1,2}$, Melanie Hempel ${ }^{1}$ and Karl-Otto Rothhaupt ${ }^{1}$ \\ 1 University of Constance, Limnological Institute, Box M 659, D-78457 Constance, Germany \\ 2 Alfred Wegener Institute for Polar and Marine Research Helgoland, Kurpromenade, D-27498 Helgoland, Germany
}

Received 5 June 2009; Accepted 10 May 2010

\begin{abstract}
Using field experiments, we investigated the effects of fish carcasses (so called 'food falls') on benthic fauna. We simulated food falls using freshly killed fish during two different seasons (spring and summer) in the littoral zone of a large, pre-alpine meso-oligotrophic lake in central Europe (Lake Constance, Germany). This study provides evidence that input in the form of fish carcasses may play an important role in nutrient dynamics within this ecosystem. The benthic communities in the vicitinity and underneath the food fall were strongly influenced by the food fall. The results show that this supply of organic matter has a significant influence on the relationships within the communities, which are clearly dominated by bacteria, followed by copepod nauplii, cyclopoid copepods, chironomids, and ostracods. Total decomposition was obtained between days 80 and 68 of the experiments. The food fall had a positively but not significant effect on meiofaunal assemblages in these experiments. Furthermore, the results showed a negative relationship between bacteria and meiofauna abundance, indicating grazing by the meiobenthos on the bacterial community. These findings support other studies that found that the meiofauna exerted a grazing pressure on the microbial community, where this process was important in the decomposition of carcasses. Moreover, this study shows the potential importance of fish carcasses in Lake Constance, where food falls may generate high abundances and diversity of the benthic fauna and support high bacterial activities in this littoral ecosystem.
\end{abstract}

Key words: Pelagic-benthic coupling / decomposition / meiofauna / bacteria / fish carcasses

\section{Introduction}

In marine deep-sea biology, nekton carcasses from fish and birds to cetaceans are well known as an important carbon-input for the deep-sea community, which in some cases solely rely on this carbon source (Isaacs and Schwartzlose, 1975). Other studies show that fish carcasses in deep sea environments may be located and consumed within hours by highly mobile scavenging assemblages (e.g., Smith et al., 1989; Thurston et al., 1995). These food falls act as a local and highly concentrated organic input in deep-sea areas (Stockton and DeLaca, 1982). In general, food falls lead to nutrient and energy transfers across ecosystem boundaries (Payne and Moore, 2006) and even to an increase in secondary productivity (Baxter et al.,

\footnotetext{
*Corresponding author: katrin.premke@ebc.uu.se
}

2004; Catchpole et al., 2006). Therefore, understanding the degradation of carcasses will provide insights into the trophic transfer of energy and nutrients and into carbon cycling in lakes (King et al., 2007).

Carrion decomposition as a pathway for nutrient cycling is also important in freshwater ecosystems. For instance, salmon (Gende et al., 2002; Schindler et al., 2003) and migratory cyprinids often spawn in rhithral (upstream) river systems at the end of the life cycle of the adults. These carcasses are then decomposed in these generally nutrition-poor spawning areas and provide a significant carbon and nitrogen source for the later offspring (Brickell and Goering, 1970; Krokhin, 1975; Bilby et al., 1996; Cederholm et al., 1999; Helfield and Naiman, 2001).

It can be assumed that fish carcasses also provide a valuable source of nutrition in lake communities because fish contain large amounts of energy in the form of 
easily digestible lipids and proteins, which facilitate a more efficient recycling of energy within the ecosystem. However, few studies have addressed this topic in lakes and marshes (Donaldson, 1967; Parmenter and Lamarra, 1991; Rask et al., 1996; Stevenson and Childers, 2004). This study aims to extend knowledge about the effects of fish carcasses on benthic biodiversity and abundance in the littoral zone.

The availability of organic matter is of vital importance to the nutrition of different trophic levels, especially in oligotrophic freshwater systems such as the large prealpine lakes in central Europe. Giere (1993, and references therein) showed that meiofaunal abundance and species composition in lake systems are strongly coupled to the presence of organic matter (Silver et al., 2002; Michiels and Traunspurger, 2005). Sander and Kalff (1993) and Hewson et al. (2003) showed that bacterial biomass and diversity in benthic food webs are often directly enhanced by the additional nutrient input.

The meiofauna and invertebrate community are considered prominent agents in the breakdown of organic material in aquatic ecosystems and hence play a crucial role in carrion decomposition (Rosi-Marshall and Wallace, 2002; Chaloner et al., 2002; Fenoglio et al., 2005). These communities are therefore assumed to significantly increase nutrient cycling and energy flow within the food web and may act as a key trophic link between bacteria and larger fauna (Findlay and Tenore, 1982; De Morais and Bodiu, 1984).

Because there is currently only little knowledge of the basic processes of fish carrion decomposition in freshwater lake systems, we first investigated the effects of large inputs of organic matter (fish carcasses) on species richness and community structure in benthic bacteria, meiobenthos, and macrobenthos to reach a better understanding of its effect on carbon and nutrient cycling.

Secondly, we were interested in an estimate of the duration of fish carcass decomposition and recycling and the associated processes. This objective is specifically related to a long-standing phenomenon in Lake Constance and other European pre-alpine lakes, where mass kills, e.g. of perch (Perca fluviatilis L.), occur from time to time in spring shortly after spawning in MarchApril (Fischer pers. obs.). During this time, adult perch migrate from their profundal over-wintering habitats at 50- to $90-\mathrm{m}$ water depths to shallow areas to spawn. Shortly after spawning, a large number of fish die. The causes of these mass kills are not yet fully comprehended, though it is thought that the depletion of body reserves might be play a role. Depending on the severity of the dieoff, dead or dying perch can be found in high numbers (up to $2-3$ perch every $10 \mathrm{~m}$ along the coastline) in about 5- to 10-m water depth.

Unfortunately, there is no detailed knowledge about the fate of this fish biomass or the subsequent degradation process by freshwater scavengers. Therefore, we studied the relative importance of bacterial and invertebrate scavenging decomposition on fish falls in the littoral zone of Lake Constance.

\section{Material and methods}

\section{Study site}

The study site was located in the temperate, oligotrophic Lake Constance, which is the second largest prealpine lake in northern Europe (Fig. 1). The experimental site was located along the southern shoreline of the Überlinger See, a fjord-like north-west extension of the Upper Lake at $47^{\circ} 41^{\prime} 30^{\prime} \mathrm{N}$ and $9^{\circ} 12^{\prime} 10^{\prime} \mathrm{E}$. The littoral zone is characterised by a $50-\mathrm{m}$ wide, shelf-like littoral zone with an adjacent slope area dropping down into the profundal zone. The substratum of the site is characterised by large stones and boulders in the very shallow area $(<1 \mathrm{~m}$ depth) followed by a sandy sediment plane with sparse macrophyte coverage down to a water depth of about $5 \mathrm{~m}$. The site is exposed to winds from the northeast that, however, only blow a few days a year. During the remainder of the year, a landward ridge covering a major part of the shoreline protects the site.

\section{Experimental setup and sampling}

We simulated food falls (FF) by exposing a total of twelve similarly sized and freshly killed perch (Perca fluviatilis L.; age class 1, standard length 13-14 cm) between March and July in a water depth of $7 \mathrm{~m}$ close to the transition zone between the littoral zone and the adjacent slope area $\left(47^{\circ} 41^{\prime} 30^{\prime \prime} \mathrm{N} ; 9^{\circ} 12^{\prime} 10^{\prime \prime} \mathrm{E}\right)$. A grid $(80 \times 50 \mathrm{~cm})$ was fixed by tent pegs on the lake bottom on which the carcasses were randomly fixed by cable clips.

Fish carcasses were sampled using continuous photographic assessment over time (see below) and by repetitive SCUBA sampling of the meiofauna, the macrofauna, and the bacterial community in three locations: a) on the fish itself (subsequently called epiphyton [EPI]); b) in the sediment below the fish [FIS-SED]; and c) at a control site at the same water depth and at a horizontal distance of $5 \mathrm{~m}$ from the fish carcasses [CON-SED].

The decomposition process of the fish was continuously photographically documented by an underwaterobservatory system called RemOs1 (Fischer et al., 2007). The system photographed still shots every $30 \mathrm{~min}$ over the entire decomposition process (up to 70 days) of the fish. This set-up allowed for a detailed assessment of the condition of the fish and the larger benthic macrofauna associated with the carcass.

Scientific divers from the University of Constance sampled the associated meiobenthos, macrobenthos and bacterial community on a weekly (spring) and biweekly (summer) basis.

At each sampling occasion, one of the twelve fish was randomly selected, removed from the grid and carefully transferred into a Cautex-bottle to avoid loss of the fishassociated community. Subsequently, sediment samples below the location where the fish was located were taken in triplicate. For this, three $20-\mathrm{mL}$ cut syringes (inner 


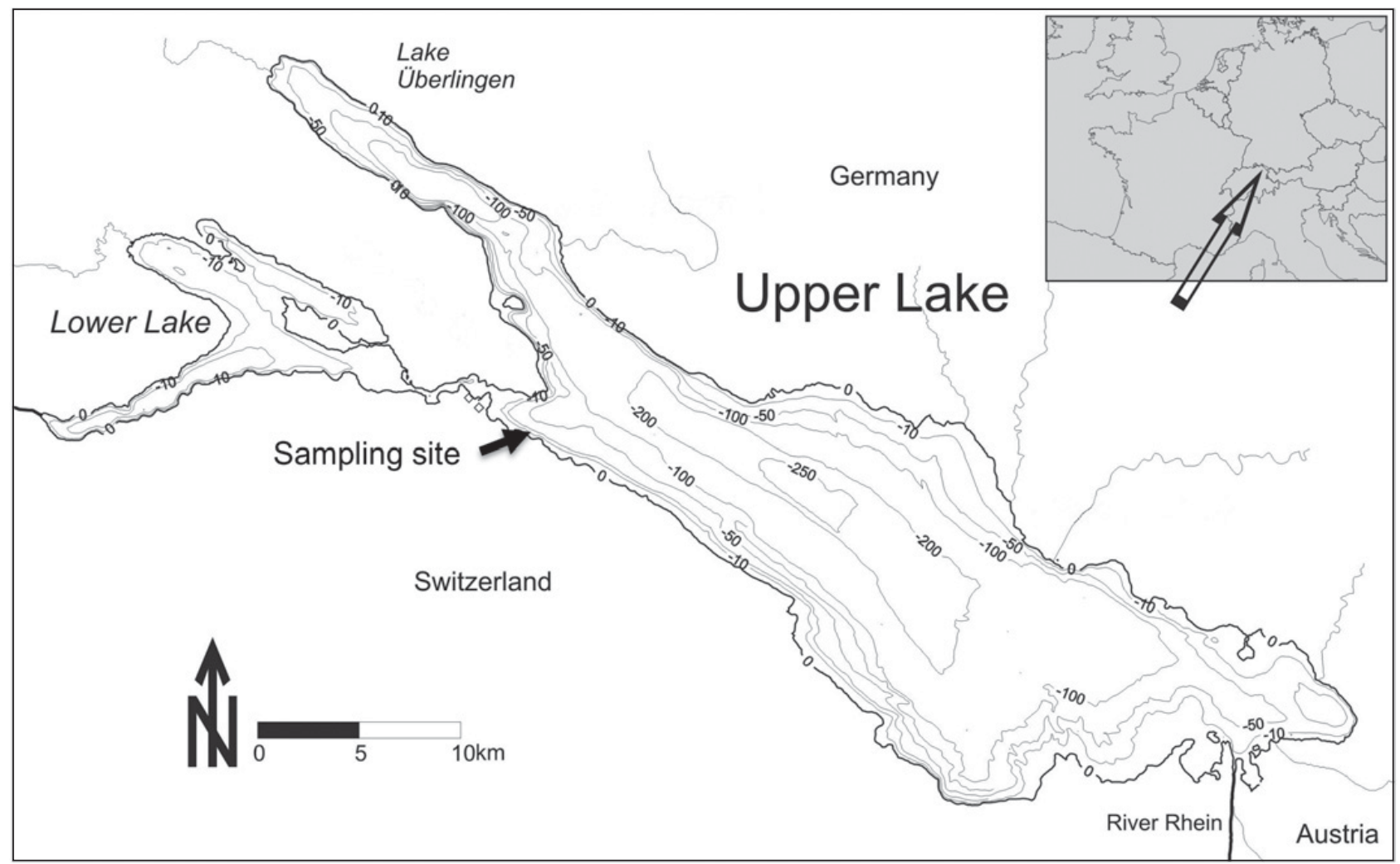

Fig. 1. Map of Lake Constance and sampling point.

diameter, $21.5 \mathrm{~mm}$ ) were carefully drawn into the sediment, closed at the front with rubbers and placed upright in a plastic carrying basket to transport them to the surface. At last, identical sediment samples were taken in triplicate at a reference site at the same water depth but at a horizontal distance $5 \mathrm{~m}$ away from the fish carcasses.

\section{Sample preparation and analyses}

The EPI samples were collected in the laboratory by carefully scraping off all epiphyton material from the carcass surface utilising sterile filtered lake water $(0.2 \mu \mathrm{m}$ to avoid contamination by external bacteria). This suspension was adjusted to $20 \mathrm{~mL}$ and fixed with formaldehyde ( $4 \%$, final concentration). One-fifth of this suspension was used for bacterial abundances and fourfifths for meio- and macrofauna abundances. These measurements were converted to the number per area by assuming that $20-\mathrm{mL}$ suspension includes $315 \mathrm{~mm}^{2}$ of fish surface.

To determine the biomass loss of the carcasses in terms of dry mass (dm) and ash-free dry mass (AFDM), the remaining portion of the fish was first dried at $70^{\circ} \mathrm{C}$ for $48 \mathrm{~h}$ and then weighed, and this was followed by combustion at $550{ }^{\circ} \mathrm{C}$ for $5 \mathrm{~h}$ and subsequent weighing.

Benthic fauna of the sediment samples FIS-SED and CON-SED was extracted from sediment by the Ludox centrifugation technique (Burgess, 2001). For meio- and macrofaunal determination, samples were sieved through a $30-\mu \mathrm{m}$ mesh net. The samples trapped on the net were fixed with $4 \%$ formaldehyde (final concentration) and stained with Bengal Rose. Organisms were counted under a stereo microscope (Zeiss, 40× magnification) and classified into taxonomic groups (oligochaetes, tardigrades, nematodes, rotifers, ostracods, gastrotriches, copepods including cyclopoida and harpacticoida, nauplii, chironomids, cladocerans, ephemeroptera, hydra, gastropods, and bivalves).

Functional groups were classified into deposit feeder (oligochaeta (Lumbriculida), gastrotriches (Chaetonotida), nematoda (Nematoda), ostracoda (Ostracoda), chironomidae (Diptera)), suspension feeder (cladocerans (Cladocera), rotifers (Rotifera), nauplii, bivalves), raptorial feeder (hydra, copepods) and grazer (gastropods).

Bacterial abundance was determined using epifluorescence microscopy (after Kemp et al., 1993). Sediment was diluted up to $10^{-3}$ with filtered tap water $(0.2 \mu \mathrm{m}$, Nucleopore). Each dilution was vortexed and sonicated (10 s, Laboson 200 ultrasonic bath, Bender and Hobein). The final dilution was filtered onto black membrane filters $(0.2 \mu \mathrm{m}, \varnothing 25 \mathrm{~mm})$. Filters were stained with DAPI (4',6-diamidino-2-phenylindol, $10 \mu \mathrm{g} . \mathrm{mL}^{-1}, 5 \mathrm{~min}$ ). The stained cells were counted under an epifluorescence microscope (Labophot 2, Nikon) at an excitation wavelength of $549 \mathrm{~nm}$. 


\section{Decomposition rate}

In addition to the effect of food falls on the associated meio- and macrofauna, we also followed the decomposition process of the fish carcasses and the associated macroscavengers over time. For this, we used the portable underwater observatory RemOs1 (Fischer et al., 2007), which took photographs of the carcasses every 30 min over the entire experimental time. For details of the system, see Fischer et al. (2007). To gain an estimate of the biomassremoval rate of the fish over time, one fish out of the twelve was removed every week, and its biomass loss was calculated in percent wet-weight, dry-mass and ash-free dry-mass loss. Because dry-mass and ash-free dry-mass of the carcasses could not be determined directly at the beginning of the experiment, these data were calculated based on the original wet-weight of the carcasses. Drymass was calculated based on a dry- to wet-weight relationship of 0.26 for perch that was calculated using previous catch data for perch in Lake Constance (Reyjol et al., 2005). Similarly, ash-free dry-mass at the time of carcasses exposure was back-calculated from the dry mass of the fish using an average dry weight to ash-free dry weight relationship of 0.75 (Johnson and Brinkhurst, 1971).

\section{Statistical analysis}

Differences in the micro-, meio- and macrofauna on, below and close to the fish carcasses were tested using a repeated measurements design (MANOV-RMA, JMP, 2007). For the analysis, the sequential sampling days were used as a "within-subject" factor (repeated or time effect), whereas water temperature and the different sampling locations, [EPI], [FISH-SED] and [CON-SED], were used as "between-subject" factors (across effect).

Fish mass decomposition decreased according to a single-slope exponential decay (nonlinear regression model, 95\% confidence interval, SPSS) and was calculated as follows:

$$
M_{t}=M_{0} \times \mathrm{e}^{-\mathrm{k} t},
$$

where $M_{t}$ is the remaining mass $(\mathrm{g})$ at time $t, M_{0}$ the initial mass $(\mathrm{g})$, and $\mathrm{k}$ the constant rate of decay $\left(\mathrm{d}^{-1}\right)$ (Elliot, 1997; Chaloner et al., 2002).

\section{Results}

In both experiments, carcasses remained widely unaffected by larger scavengers like fish or crayfish. Additionally, smaller macrofauna, like isopods or amphipods, were not observed feeding on the carcasses.

\section{Temporal succession of carcass decomposition}

The first six fish were deployed from March to May 2006, and the experiment (I) lasted for 51 days. The water temperature during this time increased from 4 to $13{ }^{\circ} \mathrm{C}$ (Figs. 3c and 3f). Decomposition rates of the carcasses were high in the first 15 days, where $50 \%$ of the original fish dry-weight biomass decomposed (Fig. 2). Then, however, the decomposition process slowed down, and $25 \%$ decomposition was observed about 25 days later. Finally, $100 \%$ of the carcasses were decomposed after approximately 80 days. This value, however, had to be extrapolated because the experiment was terminated after 51 days. The other six fish (experiment II) were deployed immediately after the first experiment from May to July 2006, and this experiment was conducted for 70 days. During this time, the water temperature further increased to a maximum of $25^{\circ} \mathrm{C}$ in July (Fig. 3f). Even though the temperatures were somewhat higher, the decomposition rate over the first five weeks of experiment II was somewhat but not significantly slower (pairwise t-test by weeks of experiment: $n=5, \mathrm{df}=4, \mathrm{t}=0.72$ ) with $50 \%$ decomposition reached after 35 days (Fig. 2). The slightly faster decomposition rate in exp. 1 during the first phase $(<5$ weeks), however, was compensated in the second phase ( $>5$ weeks), such that total decomposition of the fish in exp. II was observed after 70 days compared to the calculated 80 days in exp. 1.

Because total decomposition rates of the two experiments were not significantly different, the data for the two experiments were pooled and used in subsequent time series analyses on the macrobenthos, meiobenthos and bacterial community associated with the fish carcasses.

\section{The scavenging community}

In general, the sediment and the epifaunal samples comprised smaller macrozoobenthos, including bivalves, gastropods, and chironomids and a few ephemeroptera larvae, hydrozoa and hydracarina. In the associated meiobenthos community, we found cladocerans, copepods, ostracods, oligochaetes, nematodes, tardigrades, gastrotriches and rotifers. During the course of the experiments, an increasing amount of fungoid-like periphyton was observed on the carcasses, and the fish became more and more covered with sediment. Furthermore, irregular patches of Beggiatoa spp. developed on or in the immediate vicinity of the carcasses in both experiments. Beggiatoa is a sulfide oxidising bacteria that lives in the anoxic/oxic interface and often forms dense mats covering organic or sulfide-rich sediments (Brune et al., 2000).

\section{Fish fall effect on meiofauna assemblages}

First, the meiofauna community at the three sampling sites, EPI (on the fish carcass), FISH-SED (sediment below the fish carcass) and CON-SED (reference-site $5 \mathrm{~m}$ away at the same depth), was tested for abundance differences. RMA analysis revealed that the abundance of the meiofauna community in general was not significantly different among the three sampling sites (ANOVA 


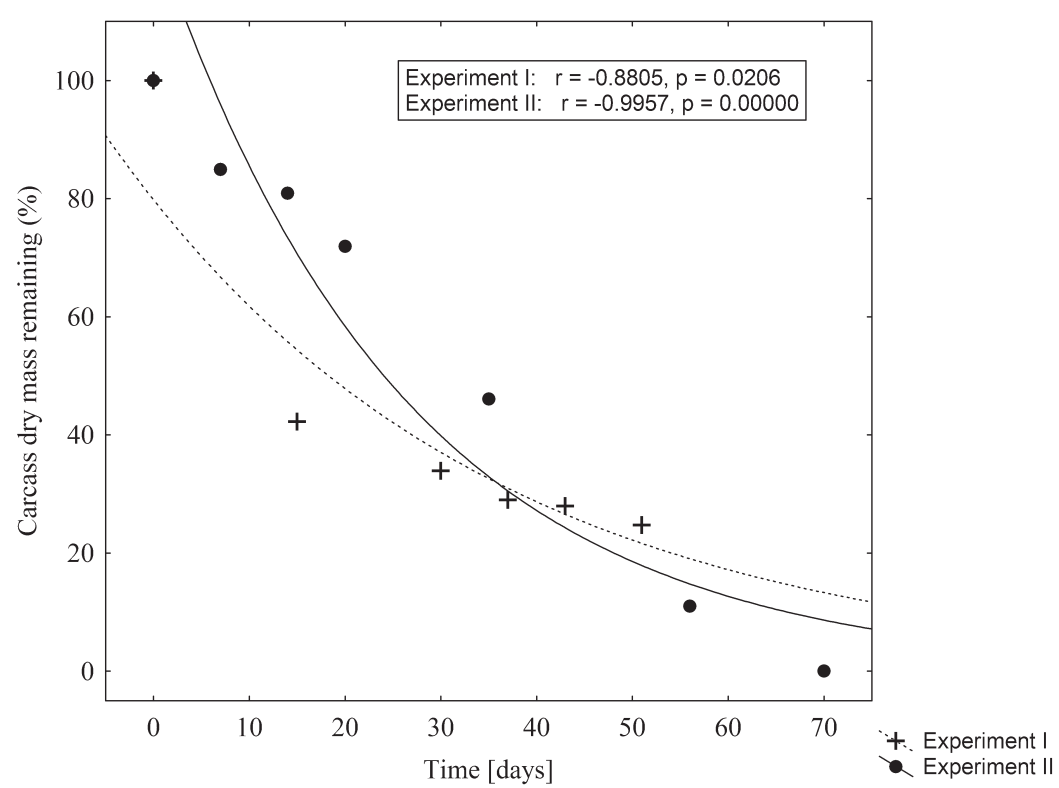

Fig. 2. Decomposition rate of perch carcasses in the littoral zone for experiment I (crosses) and II (circles). The dry-weights of the carcasses after $x$ days of exposure as a percent of the dry-weight of the fish calculated at day zero of the experiment (day of exposure) are shown. For data interpolation, an exponential function was used.

repeated measurements analysis: $\mathrm{df}=2, \mathrm{~F}=0.88, p=$ $0.55)$, even though the overall abundance of the meiofauna community on the fish carcass (EPI) increased to 2511 ind. $10 \mathrm{~cm}^{-2}$ in the fifth week of the experiment compared to only 12 ind $10 \mathrm{~cm}^{-2}$ on the sediment under the fish and 167 ind $10 \mathrm{~cm}^{-2}$ at the control site.

Looking at the meiofaunal community in more detail revealed that up to $90 \%$ of the meiofauna organisms on the fish carcasses [EPI] in experiment I were cyclopoide copepods and nauplii larvae, whereas less than 1\% (in number) were nematodes (Fig. 4). In contrast, approximately $48 \%$ of the fish-associated meiofauna in experiment II comprised cyclopoide, copepods and nauplii larvae, whereas up to $33 \%$ nematodes and $12 \%$ ostracods were found. The meiofaunal organisms at the control site [CON-SED] also differed, where nematodes dominated the community (up to $61 \%$ ), followed by copepods, nauplii larvae (28 and 25\%, respectively) and rotifers (9\%, Fig. 4).

\section{Fish fall effect on macrofauna assemblages}

When considering a $p$-value of 0.1 as significant, RMA analysis revealed a significantly higher (ANOVA repeated measurements analysis: $\mathrm{df}=2, \mathrm{~F}=12.32, p=0.07$ ) total abundance of macrofaunal organisms on the fish carcass [EPI] compared to the sediment below the fish [FISH-SED] and the control site [CON-SED]. A Pillais Spur test on the interactions between macrofaunal abundance and the time of the experiment revealed no significant interactions between time and sampling sites (Pillais Spur test: $\mathrm{df}=6.2, \mathrm{~F}=0.35, p=0.86)$. This shows a general higher abundance of macrofaunal abundance on the fish carcasses compared to the sampling sites [FISH-SED] and [CON-SED] independent of the time of the sampling.

In general, the lowest abundances of macrofaunal organisms were always found in the sediment below the fish carcasses (Fig. 3), even though these abundances were not significantly lower compared to the reference site [CON-SED]. Examining the macrobenthos community at the three sites in detail showed that the community at the EPI site contained almost $100 \%$ chironomids (Fig. 5a) in experiment I but only $40 \%$ chironomids in experiment II. Then, molluscs $(32 \%)$ and hydra $(28 \%)$ contributed in larger proportions to the scavenging macrofaunal community.

\section{Fish fall effect on bacteria occurrence}

In a third step, the bacterial abundance among the three sampling sites, EPI, FISH-SED and CON-SED, was compared (Fig. 3). Bacterial abundance at the reference site [CON-SED] was about the same as in the FISH-SED samples and up to five times lower than in the EPIsamples. Bacterial abundance on the fish carcasses [EPI] was significantly higher (ANOVA-repeated measurements analysis: $\mathrm{df}=2, \mathrm{~F}=4.7, p=0.035)$ compared to the sediment below the fish [FISH-SED] and the control site [CON-SED], where this was more significant than the pattern found in macrofaunal abundances. As already observed in the macrofaunal community, the time of the experiment did not significantly interact with the observed differences in bacterial abundance on the fish carcasses and the sediment samples (Pillais Spur test on the interactions between bacterial abundance and time of the experiment: $\mathrm{df}=20.4, \mathrm{~F}=1.44, p=0.26$ ), which indicates 

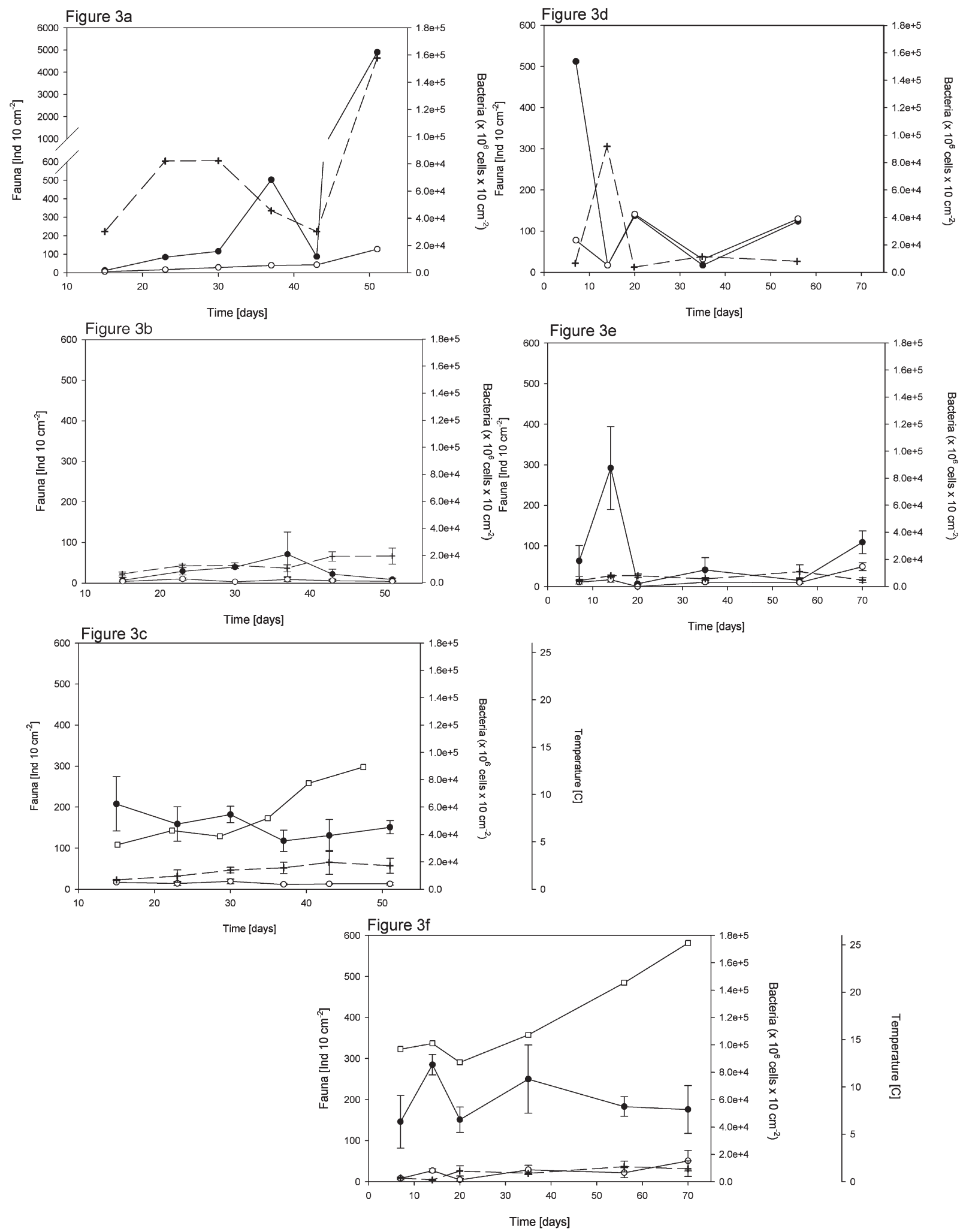

Fig. 3a-f. Distribution of bacteria (dashed line, crosses), meio- (filled circles) and macrofauna (open circles) over time (days) in a) experiment I for EPI (on the fish carcasses), b) experiment I for FIS-SED (sediment below the fish carcasses), c) experiment I for CON-SED (reference site $5 \mathrm{~m}$ away at the same depth), d) experiment II for EPI, e) experiment II for FIS-SED, and f) experiment II for CON-SED. The water temperature is also shown in c) and f) (open squares). 

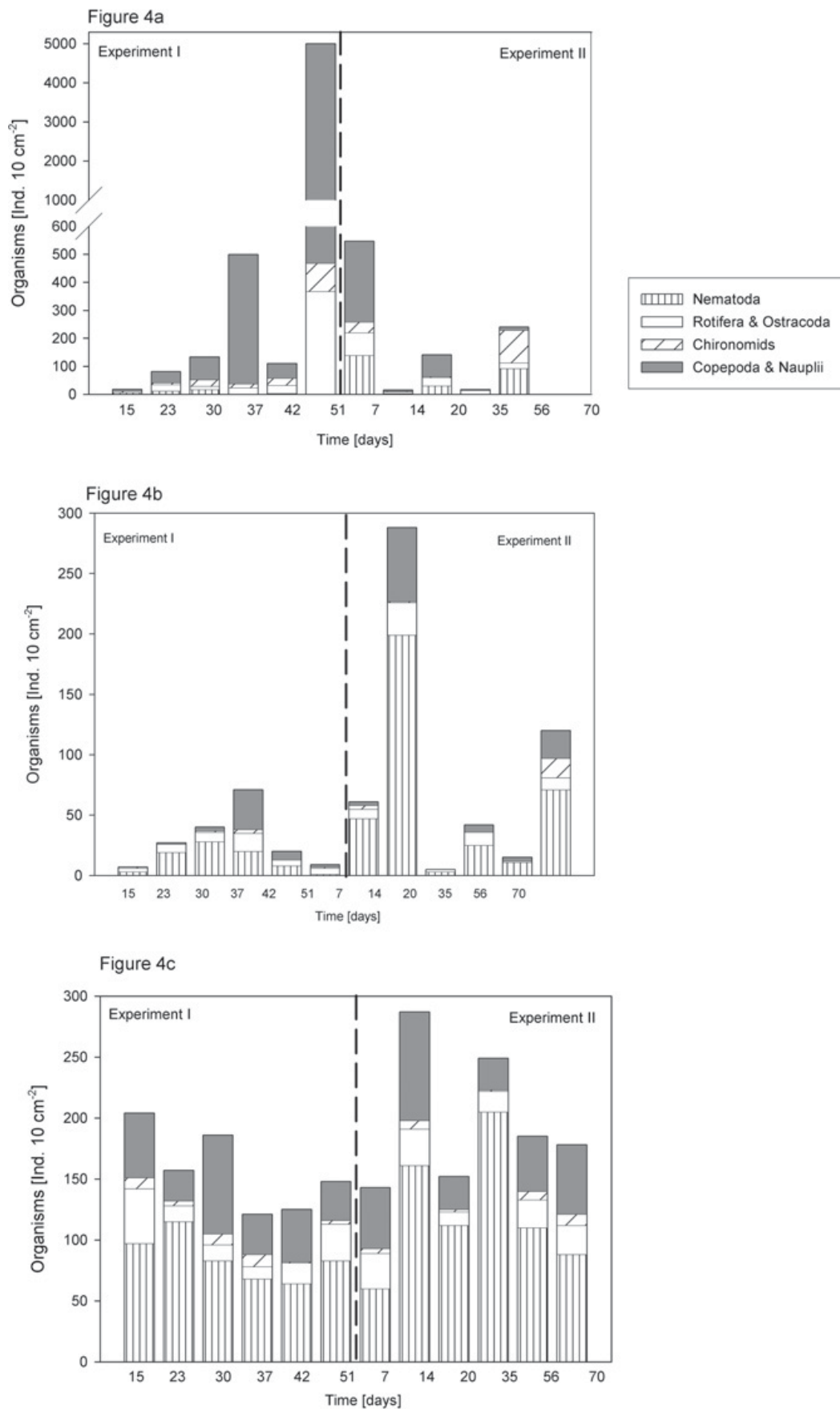

Fig. 4a-c. Fauna distribution in experiment I and II for a) EPI (on the fish carcass), b) FIS-SED (sediment below the fish carcass) and c) CON-SED (reference-site $5 \mathrm{~m}$ apart in the same depth). Only the most abundant species are given (copepoda, nauplii, nematoda, rotifera, ostracoda and chironomids). Note the different $y$-axis scales.

that the increased bacterial abundance on the fish carcasses was an independent, general pattern.

\section{Functional groups}

Concerning the functional groups, the relative contributions varied considerably over time. This was most prominent in an almost inverse abundance of deposit feeders versus suspension and raptorial feeders (Fig. 5). The abundance of deposit feeders was in general high when the total amount of benthic fauna was low. In contrast, the suspension and raptorial feeders were the major groups when the total amount of fauna was high (Fig. 5).

\section{Discussion}

\section{Degradation of carcasses in aquatic systems}

In the deep sea, it is well known that the degradation and distribution of organic matter of food falls occurs very 

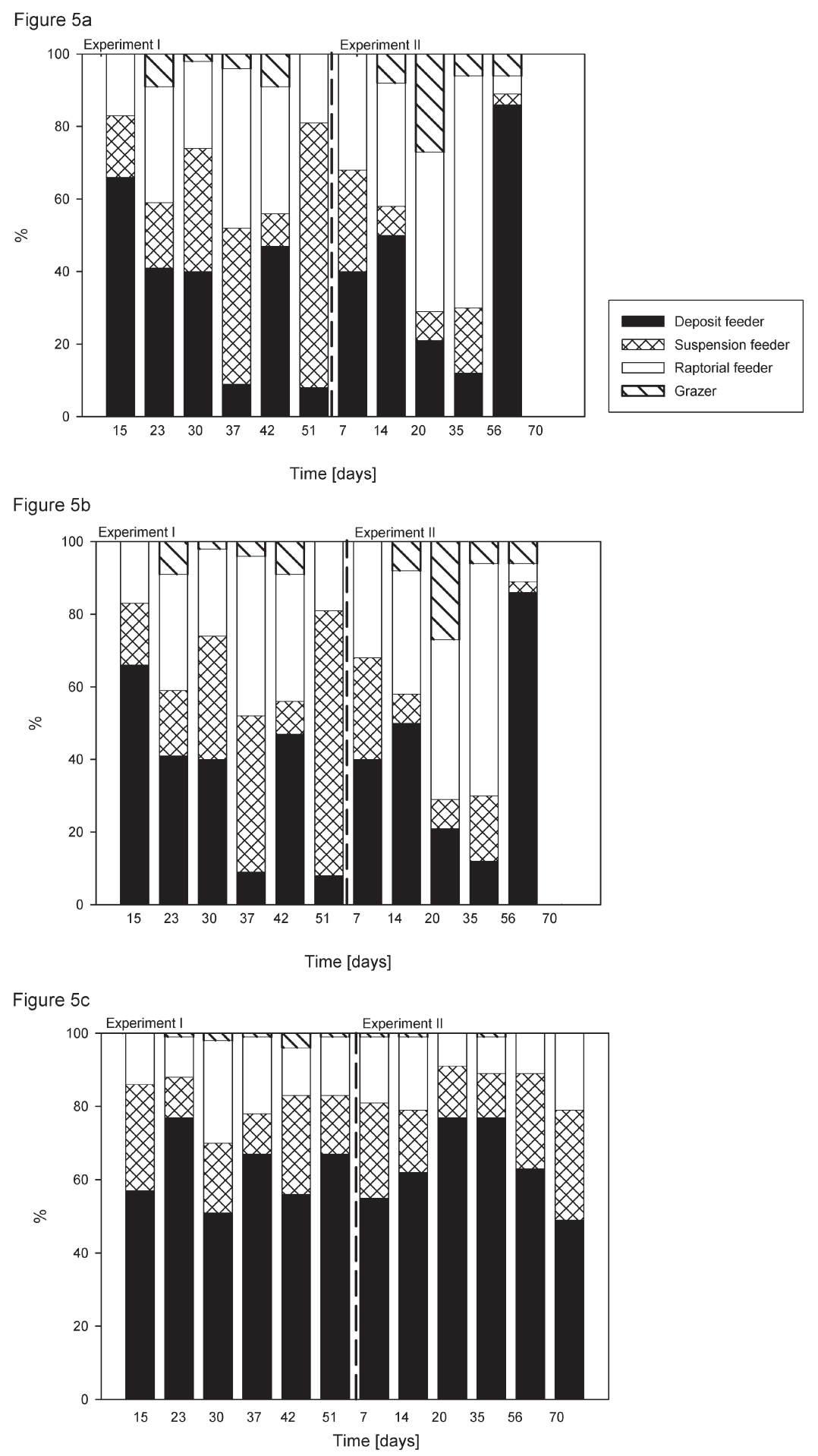

Fig. 5a-c. Functional groups in experiment I and II for a) EPI (on the fish carcass), b) FIS-SED (sediment below the fish carcass), and c) CON-SED (reference site $5 \mathrm{~m}$ away at the same depth). Functional groups included deposit feeder (oligochaeta, gastrotricha, nematoda, ostracoda, chironomidae), suspension feeder (cladocera, rotifera, nauplii, bivalvia), raptorial feeder (hydra, cyclopoide copepods) and grazer (gastropoda).

quickly ( $>2500$ g.d $\mathrm{d}^{-1}$ ) by mobile scavengers, such as crustaceans or fish (e.g. Isaacs and Schwartzlose, 1975; Premke et al., 2006). Food falls in the deep sea act as an important energy mediator from carcasses to other organisms in all trophic levels. In contrast, in freshwater environments, like in our experiments in Lake Constance, no large motile scavenging organisms, such as fish or crustaceans, were observed at the food fall by 
the underwater observatory. This indicates that fish carcasses exposed in the littoral zone of Lake Constance are hardly subjected to a severe degradation by scavenging macro-organisms. Similar observations were reported also by recreational scuba divers from Lake Constance. Fish carcasses exposed in the shallow water zone, e.g., after fish kills of perch (Perca fluviatilis L.) in spring shortly after spawning, often are observed for several weeks without any obvious sign of scavenging degradation (pers. obs.). Previous experiments in the deeper parts of Lake Constance also revealed a lack of macro-organism scavengers in this system. In baited lander experiments using an underwater camera, carrion remained untouched by scavengers for several weeks and could be recovered without any signs of macrofaunal degradation (Premke, unpub. data).

\section{Fish decomposition rate in Lake Constance}

With an average $\mathrm{k}$-value of $-0.032 \mathrm{day}^{-1}$, our results revealed a comparatively low decomposition rate compared to other studies in streams and lakes (Minshall et al., 1991; $\mathrm{k}=-0.033$ day $^{-1}$; Parmenter and Lamarra, 1991; $\mathrm{k}=-0.057 \mathrm{day}^{-1}$; Chaloner et al., 2002; Fenoglio et al., 2005; $\mathrm{k}=-0.048 \mathrm{day}^{-1}$ ).

However, in comparison to other decomposition experiments where no macroscale scavengers had access to the carrion like that of Jannasch and Wirsen (1972), decomposition rates were comparatively high, reaching $50 \%$ carrion decomposition after about 15-30 days and $100 \%$ decomposition after a maximum of 80 days.

Other studies, in contrast, suggest that decomposition rates are mainly linked to abiotic parameters such as temperature, $\mathrm{pH}$ and dissolved oxygen (Parmenter and Lamarra, 1991), and Chidami and Amyot (2008) even proposed that water temperature may be used to estimate a fish's carcass decomposition time because water temperature plays a key role in the development and growth of microbial and fungal communities (Stevenson and Childers, 2004). In our experiments, temperature had no significant effect on the total decomposition time.

These contrasting results of different studies are very interesting, and they may be explained by a hypothesis formulated by Jannasch and Wirsen (1972). According to this early study, the decomposition process of carcasses in an aquatic ecosystem is strongly dependant on an initialising decomposing process of the carcasses' hulls by larger scavengers. This process allows smaller macro- and meiofauna and the microbial community to start the disintegration of the tissue itself. Without this initial disintegration of the fish hull, total decomposition may occur much slower or not at all over even longer periods (Jannasch and Wirsen, 1972). The fact that we did not observe any macroscale scavengers in the vicinity of the carrion in our experiments may thus explain the comparatively low decomposition rate; the carcass had to be processed mainly by small scale scavengers and the microbial community and, therefore, was slower than in other experiments in which macroscale scavengers initiated the decomposition process.

However, it still remains unclear why no crayfish, amphipods or other vertebrate or invertebrate scavengers were involved in the decomposition process in our experiments, even though these species, e.g., crayfish, are present in the lake (Hirsch et al., 2008). Our samples and the photographic documentation showed that the fish in the experiment were rapidly covered by Beggiatoa spp. mats. This might have kept scavengers off of the carcasses. Beggiatoa is known to produce chemicals that repel scavengers (Kim et al., 2007). Also, Burkepile et al. (2006) showed that microbe-laden carrion was four times more likely to be uncolonised by megafaunal scavengers than was fresh carrion. The bacteria on the carcasses produce toxic chemicals that discourage scavengers. Thus, bacteria compete with scavengers by rendering carcasses chemically unattractive (Burkepile et al., 2006).

\section{Bacteria as a main decomposer}

In both experiments, the benthic communities of the littoral were strongly influenced by the food supply on the fish carcasses [EPI], which was clearly dominated by bacteria. Hence, microbes are very important for the actual decomposition of such food falls. They affect population-, community- and ecosystem-level processes as decomposers (Moore et al., 2004). The epifaunal bacterial community on the fish carcasses showed a lag phase of several days. Previous studies also found that these responses of benthic organisms to a food fall of a carcass may be immediate (Graf, 1987; Goedkoop et al., 1997) or display a lag phase from days to months (e.g., Tornblom and Bostrom, 1995).

Bacterial and meiofauna numbers were varying more between the different sites and seasons. However, a negative relationship between the bacterial numbers and the meiofaunal abundance was observed, especially in the sediment under the fish [FISH-SED] (t-test: $n=35$, $\mathrm{t}=-2.02, p=0.051)$. Such a negative relationship has been previously found in other studies, where the meiofauna, especially deposit feeders, exerted a grazing pressure on the microbial community, and this pressure was important to the general (global) nutrient cycling (e.g., Montagna and Bauer, 1988; Arndt, 1993; Schmid-Araya and Schmid, 2000). Although other studies argued the opposite, Harriague et al. (2006) found that bacteria of the littoral zone in the Mediterranean were not controlled my metazoan predatory pressure.

The sediment beneath the fish [FISH-SED] can be compared to CON-SED. Bacterial numbers were about the same and meiofauna counts were even less below the fish compared to the control site. This might be due to potentially anoxic conditions (indicated by the observed Beggiatoa colonisation of the fish), which some organisms of the meiofauna are not able to cope with (Moodley et al., 1997). 


\section{Meio- and macrofauna development during decomposition}

At the reference site $5 \mathrm{~m}$ away from the food fall [CON-SED], metazoan organisms were dominated by nematodes, followed by copopoda and nauplii larvae and rotifers (Fig. 4c). A similar pattern was also found in the profundal of Lake Brunsee, where the benthic community was dominated by nematodes followed by rotifers (Bergtold and Traunspurger, 2004). Additionally, other studies showed that soft bottoms are generally dominated by nematodes (e.g., Holopainen and Passivirta, 1977; Traunspurger, 2002; Wu et al., 2004), whereas hard bottoms are generally dominated by harpacticoid copepods, isopods and amphipods, whereas nematodes accounted for a minor fraction (Coull et al., 1983, 1995; Danovaro, 1996; Danovaro and Fraschetti, 2002).

Compared to the metazoan distribution at CON-SED, the EPI community showed a hard bottom type fauna; it was dominated by copepods and nauplii larvae, whereas nematodes accounted only for a minor fraction (Fig. 4a). These results indicate that nematodes seem to be less important within the scavenging community on fish carcasses and do not directly contribute to the decomposition rate.

\section{Micro- and macrofauna interactions during decomposition}

High bacterial numbers were found at the sampling site directly on the fish [EPI]. However, after an initial rise at the beginning of the experiment, bacteria were grazed down and then started to gain in numbers again with the decline in the meiofauna ( $90 \%$ calanoid copepods). Then, the macrofaunal community again increased in numbers, although they consisted almost entirely of chironomid larvae in this phase ( $>100$ ind $.10 \mathrm{~cm}^{-2}$ at the end of the experiment). The rapid decline of the meiofauna from days 35 to 43 might be due to the predation pressure from chironomid larvae, a process also found in other studies (Sephton, 1987; Goedkoop et al., 1998; Figs. 3a and 5a). However, this decrease in meiofauna was only a temporary effect, and the population size of bacteria and meiofauna recovered after a few days (Fig. 3a).

Even though temperature had no overall significant effect on the decomposition process, the results show that temperature and, therefore, the timing of the food fall had at least some impact on bacterial abundance (ANOVA repeated measurements analysis: $\mathrm{df}=1, \mathrm{~F}=3.6$, $p=0.084$ ), although it was only significant at the $p=0.1$ level.

The relation between meiofauna and macrofauna seemed to be mainly driven by the food exploitations, whereas predation seemed to be irrelevant. At all sites, the macrofauna seemed to be of less importance than bacteria and meiofauna, where it was constantly around $0-20$ ind. $\mathrm{cm}^{-2}$.

\section{The role of carcasses in the nutrient cycle of Lake Constance}

Many limnological studies and many data sets are available for the oligotrophic Lake Constance. As in all oligotrophic freshwater systems, the main limiting factor in Lake Constance is phosphorus, with an average P-level of $<10 \mathrm{mg} \mathrm{P} . \mathrm{m}^{-3}$. Therefore, we focused our study on the nutrient phosphorus by considering fish carcasses of perch as an important "biogenic" phosphorus source in the littoral zone of the lake. This assumption seems to be valid because perch in general form the highest fish biomasses in the shallow areas of Lake Constance (Reyjol et al., 2005).

Because it is difficult to estimate the proportion of perch mortality that become food falls in Lake Constance (Staub et al., 1998; $m=0.72$ (female), and 0.8 (male), respectively), we cannot yet estimate fish carcass availability in terms of biomass.yr ${ }^{-1}$. Other studies revealed that the regeneration and recycling of nutrients from fish carcasses through decomposition are a significant source of P (Nakashima and Leggett, 1980; Nriagu, 1983; Chidami and Amyot, 2008). However, the flux of perchbound $\mathrm{P}$ will depend on whether the carcass is deposited in the littoral versus the profundal zone. As mentioned above, carcasses in the profundal zone degraded much more slowly and remained untouched by scavengers for at least three months longer than in the littoral zone (Premke, unpub. data); thus, mineralised $\mathrm{P}$ will re-enter the food chain later. In contrast, our experiments revealed that fish carcasses in the littoral zone were degraded within 80 days, mostly by microorganisms and vertebrates. Thus, carcassbound $\mathrm{P}$ was recycled much faster into the food chain.

Even though we were not able to estimate P-recycling in our study on food fall for Lake Constance, our experiments in combination with others suggest that food falls are quite important, where such food falls may occur immediately after spring spawning. This biomass may then serve as an important resource for bacteria and meiofaunal organisms, as evidenced by the high abundances and diversity of the benthic fauna and the high bacterial activities on food falls in this littoral ecosystem. For freshwater ecosystems, 'rapid' decomposition without large scavengers suggests that fish carcasses play a key role in nutrient dynamics within this ecosystem.

Acknowledgements. The authors thank the SCUBA divers of the Limnological Institute, Constance, for sampling and C. Geiss for lab assistance. Special thanks to H. Hofmann for providing the temperature data. Thanks also to M. Klages and his research group at AWI Bremerhaven for lending the camera system. This work was funded by a German fellowship of Land BadenWürttemberg.

\section{References}

Arndt H., 1993. Rotifers as predators on components of the microbial web (bacteria, heterotrophic flagellates, ciliates) A review. Hydrobiologia, 255, 231-246. 
Baxter C.V., Fausch K.D., Murakami M. and Chapman P.L., 2004. Fish invasion restructures stream and forest food webs by interrupting reciprocal prey subsidies. Ecology, 85, 26562663.

Bergtold M. and Traunspurger W., 2004. The benthic community in the profundal of Lake Brunnsee: seasonal and spatial patterns. Arch. Hydrobiol., 160, 527-554.

Bilby R.E., Fransen B.R. and Bisson P.A., 1996. Incorporation of nitrogen and carbon from spawning coho salmon into the trophic system of small streams: Evidence from stable isotopes. Can. J. Fish. Aquat. Sci., 53, 164-173.

Brickell D.C. and Goering J.J., 1970. Chemical effects of salmon decomposition on aquatic ecosystems. In: Murpy R.S. (ed.), First International Symposium on Water Pollution Control in Cold Climates, U.S. Government Printing Office, Washington, D.C., 125-138.

Brune A., Frenzel P. and Cypionka H., 2000. Life at the oxicanoxic interface: microbial activities and adaptations. FEMS Microbiol. Rev., 24, 691-710.

Burgess B., 2001. An improved protocol for separating meiofauna from sediments using colloidal silica sols. Mar. Ecol.Prog. Ser., 214, 161-165.

Burkepile D.E., Parker J.D., Woodson C.B., Mills H.J., Kubanek J., Sobecky P.A. and Hay M.E., 2006. Chemically mediated competition between microbes and animals: Microbes as consumers in food webs. Ecology, 87, 28212831.

Catchpole T.L., Frid C.L.J. and Gray T.S., 2006. Importance of discards from the English Nephrops norvegicus fishery in the North Sea to marine scavengers. Mar. Ecol.-Prog. Ser., 313, 215-226.

Cederholm C.J.K., Murotac T. and Sibatani A., 1999. Pacific salmon carcasses: Essential contributions of nutrients and energy for aquatic and terrestrial ecosystems. Fish. Sci., 24, $6-15$.

Chaloner D.T., Wipfli M.S. and Caouette J.P., 2002. Mass loss and macroinvertebrate colonisation of Pacific salmon carcasses in south-eastern Alaskan streams. Freshw. Biol., 47, 263-273.

Chidami S. and Amyot M., 2008. Fish decomposition in boreal lakes and biogeochemical implications. Limnol. Oceanogr., 53, 1988-1996.

Coull B.C., Creed E.L., Eskin R.A., Montagna P.A., Palmer M.A. and Wells J.B.J., 1983. Phytal meiofauna from the rocky intertidal at Murrells Inlet, South Carolina. T. Am. Mic. Soc., 102, 380-389.

Coull B.C., Greenwood J.G., Fielder D.R. and Coull B.A., 1995. Subtropical Australian juvenile fish eat meiofaunaExperiments with winter whiting Sillago maculata and observations on other species. Mar. Ecol.-Prog. Ser., 125, 13-19.

Danovaro R., 1996. Detritus-bacteria-meiofauna interactions in a seagrass bed (Posidonia oceanica) of the NW Mediterranean. Mar. Biol., 127, 1-13.

Danovaro R. and Fraschetti S., 2002. Meiofaunal vertical zonation on hard-bottoms: comparison with soft-bottom meiofauna. Mar. Ecol.-Prog. Ser., 230, 159-169.

De Morais L.T. and Bodiu J.Y., 1984. Predation on meiofauna by juvenile fish in a Western Mediterranean flatfish nursery. Mar. Biol., 82, 209-215.

Donaldson J.R., 1967. The phosphorus budget of Iliamna Lake, Alaska as related to the cyclic abundance of sockeye salmon. Ph.D. dissertation, Univ. Washington, Seattle.
Elliott J.M., 1997. An experimental study on the natural removal of dead trout fry in a lake district stream. J. Fish. Biol., 50, 870-877.

Fenoglio S., Bo T.Z., Agosta P. and Cucco M., 2005. Mass loss and macroinvertebrate colonisation of fish carcasses in riffles and pools of a NW Italian stream. Hydrobiologia, 532, 111122.

Findlay S. and Tenore K.R., 1982. Effect of a free-living marine nematode (Diplolaimella chitwoodi) on detrital carbon mineralization. Mar. Ecol.-Prog. Ser., 8, 161-166.

Fischer P., Weber A., Heine G. and Weber H., 2007. Habitat structure and fish: assessing the role of habitat complexity for fish using a small, semiportable, 3-D underwater observatory. Limnol. Oceanogr.-Methods, 5, 250-262.

Gende S.M., Edwards R.T., Willson M.F. and Wipfli M.S., 2002. Pacific salmon in aquatic and terrestrial ecosystems. Bioscience, 52, 917-928.

Giere O., 1993. Meiobenthology: the microscopic fauna in aquatic sediments, Springer, Berlin, 328 p.

Goedkoop W., Gullberg K.R., Johnson R.K. and Ahlgren I., 1997. Microbial response of a freshwater benthic community to a simulated diatom sedimentation event: Interactive effects of benthic fauna. Microb. Ecol., 34, 131-143.

Goedkoop W., Sonesten L., Markensten H. and Ahlgren G., 1998. Fatty acid biomarkers show dietary differences between dominant chironomid taxa in Lake Erken. Freshw. Biol., 40, 135-143.

Graf G., 1987. Benthic energy-flow during a simulated autumn bloom sedimentation. Mar. Ecol.-Prog. Ser., 39, 23-29.

Harriague A.C., Gaozza L., Montella A. and Misic C., 2006. Benthic communities on a sandy Ligurian beach (NW Mediterranean). Hydrobiologia, 571, 383-394.

Helfield J.M. and Naiman R.J., 2001. Effects of salmon-derived nitrogen on riparian forest growth and implications for stream productivity. Ecology, 82, 2403-2409.

Hewson I., Vargo G.A. and Fuhrman J.A., 2003. Bacterial diversity in shallow oligotrophic marine benthos and overlying waters: Effects of virus infection, containment, and nutrient enrichment. Microb. Ecol., 46, 322-336.

Hirsch P.E., Nechwatal J. and Fischer P., 2008. A previously undescribed set of Saprolegnia spp. in the invasive spinycheek crayfish (Orconectes limosus, Rafinesque). Arch. Hydrobiol., 172, 161-165.

Holopainen I.J. and Passivirta L., 1977. Abundance and biomass of the meiozoobenthos in the oligothrophic and mesohumic Lake Pääjarvi, southern Finnland. Ann. Zool. Fenn., 14, 124-134.

Isaacs J.D. and Schwartzlose R.A., 1975. Active animals of deepsea floor. Sci. Am., 233, 85-91.

Jannasch H.W. and Wirsen C.O., 1972. Alvin and the sandwich. Oceanus, 16, 20-22.

JMP, 2007. JMP Statistics and Graphics Guide, Release 7, SAS Institute Inc., SAS Campus Drive, Cary, North Carolina.

Johnson M.G. and Brinkhurst R.O., 1971. Production of benthic macroinvertebrate of bay of Quinte and Lake Ontario 2. J. Fish. Res. Board. Can., 28, 1699.

Kemp P.F., Sherr B.F., Sherr E.B. and Cole J.J., 1993. Handbook of methods in aquatic microbial ecology, Lewis publisher, Boca Raton, Florida. 
Kim S.L., Thurber A., Hammerstrom K. and Conlan K., 2007. Seastar response to organic enrichment in an oligotrophic polar habitat. J. Exp. Mar. Biol. Ecol., 346, 66-75.

King N.J., Bailey D.M. and Priede I.G., 2007. Role of scavengers in marine ecosystems. Mar. Ecol.-Prog. Ser., 350, 175-178.

Krokhin E.M., 1975. Transport of nutrients by salmon migration from the sea into the lakes. In: A.D. Hasler (ed.), Coupling of Land and Water Ecosystem, Springer-Verlag, New York, 153-156.

Michiels I.C. and Traunspurger W., 2005. Impact of resource availability on species composition and diversity in freshwater nematodes. Oecologia, 142, 98-103.

Minshall G.W., Hitchcock E. and Barnes J.R., 1991. Decomposition of Rainbow Trout (Oncorhynchus mykiss) carcasses in a forest stream ecosystem inhabited only by nonanadromous fish populations. Can. J. Fish. Aquat. Sci., 48, 191-195.

Montagna P.A. and Bauer J.E., 1988. Partitioning radiolabeled thymidine uptake by bacteria and meiofauna using metabolic blocks and poisons in benthic feeding studies. Mar. Biol., 98, 101-110.

Moodley L., Vanderzwaan G.J., Herman P.M.J., Kempers L. and Vanbreugel P., 1997. Differential response of benthic meiofauna to anoxia with special reference to Foraminifera (Protista: Sarcodina). Mar. Ecol.-Prog. Ser., 158, 151-163.

Moore J.C., Berlow E.L., Coleman D.C., De Ruiter P.C., Dong Q., Hastings A., Johnson N.C., McCann K.S., Melville K., Morin P.J., Nadelhoffer K., Rosemond A.D., Post D.M., Sabo J.L., Scow K.M., Vanni M.J. and Wall D.H., 2004. Detritus, trophic dynamics and biodiversity. Ecol. Lett., 7, 584-600.

Nakashima B.S. and Leggett W.C., 1980. The role of fish in the regulation of phosphorus availability in lakes. Can. J. Fish. Aquat. Sci., 37, 1540-1549.

Nriagu J.O., 1983. Rapid decomposition of fish bones in Lake Eric sediments. Hydrobiologia, 106, 217-222.

Parmenter R.R. and Lamarra V.A., 1991. Nutrient cycling in a fresh-water marsh - The decomposition of fish and waterfowl carrion. Limnol. Oceanogr., 36, 976-987.

Payne L.X. and Moore J.W., 2006. Mobile scavengers create hotspots of freshwater productivity. Oikos, 115, 69-80.

Premke K., Klages M. and Arntz W.E., 2006. Aggregations of Arctic deep-sea scavengers at large food falls: temporal distribution, consumption rates and population structure. Mar. Ecol.-Prog. Ser., 325, 121-135.

Rask M., Jarvinen M., Kuoppamaki K. and Poysa H., 1996. Limnological responses to the collapse of the perch population in a small lake. Ann. Zool. Fenn., 33, 517-524.

Reyjol Y., Fischer P., Lek S., Rösch R. and Eckmann R., 2005. Studying the spatiotemporal variation of the littoral fish community in a larger prealpine lake, using Self-Organizing mapping. Can. J. Fish. Aquat. Sci., 62, 2294-2302.

Rosi-Marshall E.J. and Wallace J.B., 2002. Invertebrate food webs along a stream resource gradient. Freshw. Biol., 47, 129-141.

Sander B.C. and Kalff J., 1993. Factors controlling bacterial production in marine and fresh-water sediments. Microb. Ecol., 26, 79-99.

Schindler D.E., Scheuerell M.D., Moore J.W., Gende S.M., Francis T.B. and Palen W.J., 2003. Pacific salmon and the ecology of coastal ecosystems. Front. Ecol. Environ., 1, 31-37.

Schmid-Araya J.M. and Schmid P.E., 2000. Trophic relationships: integrating meiofauna into a realistic benthic food web. Freshw. Biol., 44, 149-163.

Sephton T.W., 1987. Some observations on the food of larvae of Procladius bellus (Diptera, Chironomidae). Aquat. Insect., 9, 195-202.

Silver P., Palmer M.A., Swan C.M. and Wooster D., 2002. The small-scale ecology of freshwater meiofauna. In: Freshwater Meiofauna: Biology and Ecology, Backhuys Publishers, Leiden.

Smith C.R., Kukert H., Wheatcroft R.A., Jumars P.A. and Deming J.W., 1989. Vent Fauna on Whale Remains. Nature, $341,27-28$.

Staub E., Egloff K., Kramer A. and Walter J., 1998. The effect of predation by wintering cormorants Phalacrocorax carbo on grayling Thymallus thymallus and trout (Salmonidae) populations: two case studies from Swiss rivers. J. Appl. Ecol., 35, 607-610.

Stevenson C. and Childers D.L., 2004. Hydroperiod and seasonal effects on fish decomposition in an oligotrophic everglades marsh. Wetlands, 24, 529-537.

Stockton W.L. and DeLaca T.E., 1982. Food falls in the deepsea-Occurrence, quality, and significance. Deep-Sea Res., 29, 157-169.

Thurston M.H., Bett B.J. and Rice A.L., 1995. Abyssal megafaunal necrophages-Latitudinal differences in the Eastern North Atlantic Ocean. Int. Rev. Ges. Hydrobiol., 80, 267-286.

Tornblom E. and Bostrom B., 1995. Benthic microbial response to a sedimentation event at low-temperature in sediments of a eutrophic lake. Mar. Freshwater Res., 46, 33-43.

Traunspurger W., 2002. Nematoda. In: Rundle R.S., Robertson A.L. and Schmid-Araya J.M. (eds.), Freshwater meiofauna: Biology and ecology, Backhuys publishers, Leiden.

Wu J.H., Fu C.Z., Liang Y.L. and Chen J.K., 2004. Distribution of the meiofaunal community in a eutrophic shallow lake of China. Arch. Hydrobiol., 159, 555-575. 